\title{
Chemical control of epibiosis by Hong Kong sponges: the effect of sponge extracts on micro- and macrofouling communities
}

\author{
Sergey Dobretsov, Hans-Uwe Dahms, Mandy Y. Tsoi, Pei-Yuan Qian* \\ Marine Coastal Laboratory and Department of Biology, Hong Kong University of Science and Technology, Clear Water Bay, \\ Kowloon, Hong Kong SAR
}

\begin{abstract}
The relationship between antifouling metabolite production and epibiosis on the surfaces of the sponges Haliclona cymaeformis, Haliclona sp. and Callyspongia sp. was investigated in this study. Densities of macrofoulers and diatoms were suppressed on the surfaces of all examined sponges, while densities of bacteria on the surfaces of $H$. cymaeformis and Callyspongia sp. were similar to those on the reference surfaces and were more than double the densities of bacteria on the surfaces of Haliclona sp. compared with a reference surface. Bray-Curtis similarity matrices of the tRFLP (terminal restriction fragment length polymorphism) analysis of PCR-amplified bacterial 16S rRNA genes obtained from the surfaces of the sponges demonstrated that the bacterial communities on the sponge surfaces were different from each other and from those on the reference surfaces. In field experiments, both methanol and dichloromethane extracts from all tested sponges incorporated in a Phytagel matrix inhibited recruitment of diatoms, algae and invertebrates, but extracts of only 2 sponges deterred bacterial film development. The tRFLP analysis revealed that the sponge extracts decreased diversity in the bacterial community. Strong negative effects of the sponge extracts on the Shannon-Wiener diversity values, as well as the species-richness values of the diatom community were found. ANOSIM (analysis of similarity) and SIMPER (similarity percentage) analyses demonstrated that the type and species specificity of the extracts affected the diatom composition. Results suggest that metabolites of sponges can control recruitment of propagules, change the composition of micro- and macrofouling communities and, in this way, regulate epibiosis on sponge surfaces.
\end{abstract}

KEY WORDS: Sponge $\cdot$ Chemical defense $\cdot$ Secondary metabolites $\cdot$ Microfouling community Macrofouling community · Bacteria · Diatoms · Epibiosis

Resale or republication not permitted without written consent of the publisher

\section{INTRODUCTION}

Surfaces in the marine environment are continuously exposed to and colonized by microorganisms and propagules of metacellular organisms (Wahl 1989). As a result, complex communities of fouling organisms populate many marine surfaces. Bacteria and diatoms are among the first organisms that attach onto surfaces (Characklis \& Cooksey 1983) and form natural biofilms that are highly variable over time and heterogeneous in composition (Qian et al. 2003). The settlement of organisms on the surfaces of living organisms (i.e. epibiosis) can be both advantageous and disadvantageous to the host. Advantages could be the production of antifouling substances by symbiotic epibiota (Walls et al. 1993, Harder et al. 2003, Piel 2004) and furnishing the host with nutrients (Mercado et al. 1998, Faulkner et al. 2000). The disadvantages include the possible inhibition of growth, necrosis, or death of host organisms (Wahl \& Mark 1999). On soft-bodied marine organisms, such as sponges, the extent of microbial colonization is possibly influenced by the chemical effects of bioactive metabolites produced either by the host itself or by symbiotic microorganisms (Lee et al. 
2001, Kelly et al. 2003). Such chemical effects lead to the formation of the distinctive microbial communities that are associated with sponges.

Several investigations have shown that the microbiota from sponges differ from those associated with non-living substrata in the ambient proximity (Hentschel et al. 2003, Thoms et al. 2003, Lee \& Qian 2004, Taylor et al. 2004), suggesting that microbialsponge associations are specific. Hentschel et al. (2002) demonstrated, for example, that the sponges Aplysina aerophoba and Theonella swinhoei have a uniform internal microbial community that is different from the microbial community in the ambient environment of the sponges and from microbial plankton.

Data available on the density of epibiotic bacteria on the surface of sponges are limited and incomplete. Bacterial numbers have been estimated at $6.4 \pm 4.6 \times$ $10^{8} \mathrm{~g}^{-1}$ tissue of the sponge Aplysina aerophoba (Friedrich et al. 2001) and $1.5 \times 10^{8}$ to $8.3 \times 10^{9} \mathrm{ml}^{-1}$ sponge extract for Rhopaloides odorable (Webster \& Hill 2001). It has been shown that the number of colony-forming bacteria from the surface of the sponge Ircinia ramosa ranged from 7 to $15 \times 10^{6}$ colony-forming units $\mathrm{cm}^{-2}$ (Thakur \& Anil 2000).

Sponges are known to be rich sources of unique and diverse bioactive metabolites that provide potent antibacterial, antifungal, antifeeding, and/or antifouling protection (Austin 2001, Sera et al. 1999, Faulkner 2000, Blunt et al. 2003). At the same time, there is only limited evidence as yet on the functionality of these compounds in the natural environment against naturally occurring antagonists, such as micro- and macrofoulers. In previous laboratory and field experiments, we demonstrated that extracts from the 7 dominant sponge species in Hong Kong waters have the potential to reduce or inhibit the recruitment of bacteria and diatoms in the sea (Dobretsov et al. 2005). The sponge Callyspongia pulvinata can affect the recruitment of micro- and macrofoulers not only on its surface, but also on non-living substrates nearby (Dobretsov et al. 2004).

The sponge species Haliclona cymaeformis, Haliclona sp. and Callyspongia sp. are rarely affected by fouling in Hong Kong coastal waters. From preliminary observations, we hypothesized that these sponges and/or their microbial associates produce compounds that can affect the colonization of micro- and macroorganisms by increasing the abundance of some species and decreasing the abundance of others. In the present study, we qualitatively and quantitatively compared bacterial communities on sponge surfaces and on inanimate surfaces. For the first time, scanning electron microscopy (SEM) was used to visualize bacteria on the surfaces of the sponges. Crude extracts of the sponges were incorporated in a Phytagel matrix (cf.
Henrikson \& Pawlik 1995) that was subsequently deployed as a substratum for attachment and colonization by bacteria, diatoms, macroalgae and invertebrates under field conditions. The bacterial community profiles developed on matrix surfaces at the end of the experiments were compared by the culture-independent, PCR-based molecular fingerprinting technique of terminal restriction fragment length polymorphism (tRFLP) (Liu et al. 1997). This approach allowed us to overcome the disadvantages associated with culturedependent techniques and revealed the effects of sponge metabolites on bacterial colonization under natural conditions (Harder et al. 2004).

In the present study, we posed the following questions: (1) Are there differences in the density and composition of microbial communities on the surfaces of the 3 sponge species Haliclona cymaeformis, Haliclona sp. and Callyspongia sp. compared to inanimate surfaces? (2) Do sponge extracts affect the formation of microfouling and macrofouling communities in field experiments? (3) Is there a correspondence between epibiosis on the surfaces of sponges and the antifouling activity of sponge extracts?

\section{MATERIALS AND METHODS}

Collection of sponges and preparation of extracts. Specimens of the sponges Haliclona cymaeformis (ZMAPOR 17602), Haliclona sp. (ZMAPOR 17600) and Callyspongia sp. (ZMAPOR 17596) were collected from Hong Kong coastal waters at depths of 1 to $3 \mathrm{~m}$, near the Hong Kong University of Science and Technology Pier $\left(22^{\circ} 21^{\prime} \mathrm{N}, 114^{\circ} 17^{\prime} \mathrm{E}\right)$. The sponges were carefully retrieved to the water surface. Five sponge species specimens were cut into several portions. One piece of about $10 \mathrm{ml}$ biovolume of each sponge was used for tRFLP analysis. Another portion was stored in $70 \%$ ethanol for subsequent taxonomic identification by Prof. Rob van Soest (Zoological Museum, University of Amsterdam). A small intact piece of sponge tissue was fixed in $3 \%$ glutaraldehyde (in artificial seawater free of calcium and magnesium) for SEM analysis. We measured the wet weight of the major part of the sponge $(>500 \mathrm{~g})$ at the pier, and the tissue volume was measured by water displacement. The sponge species were transferred to large buckets with aerated seawater and brought to the laboratory.

In the laboratory, the remaining intact sponge tissues were cut into 2 equal portions of a wet weight of about 180 to $200 \mathrm{~g}$. One portion was extracted twice with dichloromethane (DCM, Fisher Chemicals) for $8 \mathrm{~h}$ with gentle agitation; the other portion was extracted with $99.9 \%$ methanol ( $\mathrm{MeOH}$, Merck) in the same way. The extracts were filtered through Whatman No. 1 filter 
paper and reduced by rotary evaporation to a concentration that was volumetrically equivalent to $10 \%$ of the original sample tissue. Tissue-level concentrations (Jensen et al. 1996) were adjusted prior to the experiments described below.

Gel-immobilization of sponge tissue extracts. The method for immobilization of the organic tissue extracts into gels was adapted from that described by Henrikson \& Pawlik (1998) and Harder et al. (2004), with slight modification. The sponge extracts were dissolved in dimethyl sulfoxide (DMSO) at a concentration 10 times that of the tissue level. Gels were prepared by adding Phytagel (Sigma Chemical) to a stirred beaker containing boiling double-distilled water to yield a $4 \%(\mathrm{w} / \mathrm{v})$ gel concentration. After the gel solution cooled down to $70^{\circ} \mathrm{C}$, the crude extracts were diluted to tissue-level concentrations with the gel solution and vigorously mixed for even distribution of the extract in the gel. A control was prepared with a pure DMSO solution instead of the crude extracts. Finally, 5-ml portions of the hot Phytagel solution were poured to Falcon Petri dishes and allowed to solidify slowly. The Petri dishes were stored overnight at $4{ }^{\circ} \mathrm{C}$ to allow for homogeneous diffusion of the extract components throughout the gel. These dishes were used in the experiments described below.

Scanning electron microscopy. Small pieces of the 3 sponge species and reference substrata (stones and shells from the close vicinity of the sponges) were dehydrated in an alcohol series, dried by critical-point drying and coated with gold (for details see Dobretsov \& Qian 2002). The specimens were then examined by a JEOL $6300 \mathrm{~F}$ (70 eV) scanning electron microscope. Bacterial counts were made by 6 randomly selected fields of view (square $=500 \mu^{2}$ ) per replicate. The densities of the bacteria were calculated as the number of cells per square millimeter of the sponge surface.

Field experiments. Gel-coated Petri dishes were exposed to fouling during $3 \mathrm{wk}$ at the Hong Kong University Science and Technology Pier $\left(22^{\circ} 21^{\prime} \mathrm{N}\right.$, $\left.114^{\circ} 17^{\prime} \mathrm{E}\right)$ at a depth $1 \mathrm{~m}$ below the low water mark. The long exposure time in our experiment was necessitated by the low fouling rate during the winter period in Hong Kong waters (Qiu et al. 2003). There were 13 replicates per treatment. After the first week, 8 Petri dishes were harvested. Five of them were then fixed in $4 \%$ formaldehyde solution in seawater for the subsequent enumeration of bacteria and diatoms. The dominant species of diatoms on the dishes were determined in 10 randomly selected fields of view under the microscope (Axiophot, Zeiss; magnification: 400×) using a key to the marine benthic diatoms of China (Jin et al. 1985). The attached bacteria were visualized by the DNA-binding fluorochrome 4,6-diamidino-2- phenylindole (DAPI, Fluka Chemie) at $0.5 \mu \mathrm{g} \mathrm{ml}^{-1}$. Formalin-fixed ( $4 \%$ in filtered [0.22 $\mu \mathrm{m}$ ] seawater [FSW]) dishes were rinsed with autoclaved $\left(120^{\circ} \mathrm{C}\right.$ for $\left.30 \mathrm{~min}\right)$ FSW and stained with DAPI for $15 \mathrm{~min}$. The number of bacteria in 5 randomly selected fields of view was estimated by epifluorescence microscopy (Olympus, Japan, magnification: 1000 $x_{i} \lambda_{\mathrm{Ex}}=359 \mathrm{~nm}, \lambda_{\mathrm{Em}}=$ $441 \mathrm{~nm})$. Three other Petri dishes were used for the analysis of bacterial communities developed on the dishes. After $3 \mathrm{wk}, 5$ additional Petri dishes were fixed in $4 \%$ formaldehyde solution in seawater for subsequent analysis of the macrofouling communities. Densities of the settlers (ind. $\mathrm{cm}^{-2}$ ) were determined under the microscope (magnification: $0.63 \times$ ).

Analysis of bacterial communities. We compared bacterial communities by tRFLP analysis (Liu et al. 1997). For this purpose, the entire surface area $\left(19.625 \mathrm{~cm}^{2}\right)$ of the experimental and control Petri dishes or $10.0 \mathrm{~cm}^{2}$ surface areas of the sponges and reference substrata were completely swabbed with sterile cotton buds. Swabs from each gel were individually suspended in $1 \mathrm{ml}$ of extraction buffer (100 mM Tris$\mathrm{HCl}, 100 \mathrm{mM}$ EDTA, $100 \mathrm{mM}$ sodium phosphate, $1.5 \mathrm{M}$ sodium chloride, $1 \% \mathrm{CTAB}_{\text {; }}$ at $\mathrm{pH}$ 8) in 2-ml microcentrifuge tubes. For lysing, the samples were subjected to 3 cycles of freezing and thawing followed by $2 \mathrm{~h}$ of incubation in $20 \%$ sodium dodecylsulfate (SDS) at $65^{\circ} \mathrm{C}$. The cotton buds were removed, and, after centrifugation (10 $000 \mathrm{rpm}$ for $5 \mathrm{~min}$ ), the total DNA in the supernatant was extracted and purified twice in a volume of 24:1 chloroform:isoamyl-alcohol, followed by precipitation in isopropanol at room temperature for $15 \mathrm{~min}$. The precipitated DNA was washed with cold $70 \%$ ethanol and resuspended in $50 \mu \mathrm{l}$ of autoclaved, double-distilled water and frozen until use.

The 16S rRNA genes (rDNA) of the bacterial community were amplified by polymerase chain reaction (PCR) in a total volume of $25 \mu \mathrm{l}$, containing $1 \mu \mathrm{l}$ of DNA template, $250 \mu \mathrm{M}$ of each desoxyribonucleotide triphosphate (dATP, dCTP, dGTP, dTTP; Pharmacia Biotechnology, USA), 1 U of DNA Taq polymerase (Amersham Biosciences, USA) and $0.8 \mu \mathrm{M}$ of each universal primer: $341 \mathrm{~F}$ forward (5'-CCTACGGGAGGCAGCAG-3') and 926R reversal (5'-CCGTCAATTCCTTTRAGTTT-3') (Amann et al. 1990, Lee et al. 1993). The 926R primer was labeled at the $5^{\prime}$-end with 6 -carboxy fluorescein (FAM) dye.

The thermocycling conditions were as follows: a hot start at $95^{\circ} \mathrm{C}$ for 2 min $(1 \mathrm{cycle})$ and 15 cycles of $95^{\circ} \mathrm{C}$ for $30 \mathrm{~s}, 56^{\circ} \mathrm{C}$ for $3 \mathrm{~min}$ and $72^{\circ} \mathrm{C}$ for $3 \mathrm{~min}$. The annealing temperature started at $56^{\circ} \mathrm{C}$ and was reduced to $40^{\circ} \mathrm{C}$ in increments of $1^{\circ} \mathrm{C}$ cycle ${ }^{-1}$. The amplified DNA ( $4 \mu \mathrm{l}$ of the PCR mixtures) was visualized by gel electrophoresis on a $1.5 \%$ agarose gel in Tris-acetateethylenediaminetetraacetic acid (TAE) buffer. 
Fluorescently labeled PCR products were then purified with the Wizard PCR preps DNA purification system (Promega) according to the manufacturer's protocol. Purified amplicons were digested with $20 \mathrm{U}$ MspI (Boehringer Mannheim Biochemicals) at $37^{\circ} \mathrm{C}$ for $6 \mathrm{~h}$. Aliquots of digested products $(10 \mu \mathrm{l})$ were mixed with $0.5 \mu \mathrm{l}$ of internal size standard (ET550-R, Amersham Biosciences). This mixture was denatured for $2 \mathrm{~min}$ at $95^{\circ} \mathrm{C}$ and immediately chilled on ice prior to capillary electrophoresis on a MegaBACE genetic analyzer (Amersham Biosciences) operated in the genotyping mode. After electrophoresis, the lengths of the fluorescently labeled terminal restriction fragments (TRFs) were determined by comparison with internal size standards by using the software 'Fragment Profiler' (Amersham Biosciences). TRFs that differed by $<1 \mathrm{bp}$ were considered identical. Fragment lengths that were present in 3 samples were used to produce a representative TRF profile of each bacterial community.

Statistical analyses. The densities of bacteria, diatoms and macrofoulers on the Petri dishes and on the surfaces of the sponges were log-transformed in order to ensure normality of variance (Zar 1999). In the case of the absence of diatoms in a field of view, a value of $\log (y+1)$ was assigned to improve the transformation. In all cases, the normality assumption was verified with the Shapiro-Wilk test (Shapiro \& Wilk 1965). The differences between the experimental and control treatments were determined by 1-way ANOVA, followed by the Tukey HSD (honestly significant differences) post hoc test (Zar 1999). In all cases, the threshold for significance was $5 \%$. TRF patterns of different bacterial community DNA samples were subjected to cluster analysis. Bray-Curtis similarities were used to produce a similarity matrix based on the total number of TRFs observed in all samples and the presence or absence of these TRFs in individual samples. For the construction of a dendrogram demarcating the similarity of microbial communities on the gels, group average linkage in the hierarchical, agglomerative clustering algorithm was performed using the PRIMER program (Plymouth Marine Laboratory, UK). As a measure of diatom and macrofouling species diversity, Shannon's diversity index $\left(H^{\prime}\right)$ and evenness (Warwick \& Clarke 1995, Clarke \& Gorley 2001) were calculated by using PRIMER. Margalef's species richness (Warwick \& Clarke 1995) was also calculated. Similarity percentage analysis (SIMPER) (Clarke 1993) was used to determine the taxa contributing most to the dissimilarity between groups. All these analyses were done using the Bray-Curtis similarity coefficient (Clarke 1993) applied to the 4th-root-transformed diatom species-abundance data. Analyses were performed using the PRIMER software package. Assemblage similarity was compared between the sponge species (sponge effect) and among the different solvents (solvent effect) using 2-way ANOSIM (Clarke \& Warwick 1994).

\section{RESULTS}

\section{Microbial epibiosis on the surfaces of sponges}

The densities of epibiotic bacteria revealed by SEM on the surfaces of Haliclona sp. were higher (ANOVA, $F=17.8$; HSD, $\mathrm{p}<0.05$ ) than on the surfaces of other sponges and on the reference surfaces (Fig. 1). The densities of epibiotic bacteria on the surfaces of H. cymaeformis and Callyspongia sp. were not significantly different from each other or from the reference surfaces (ANOVA; HSD, p > 0.05). No invertebrates, diatoms, or macroalgae were found to be attached onto any surface of the sponges, while diatoms (density: 2000 cells $\mathrm{mm}^{-2}$ ), the tubeworm Hydroides elegans (density: 3.2 ind $\mathrm{cm}^{-2}$ ) and the barnacle Balanus trigonus (density: 0.2 ind $\mathrm{cm}^{-2}$ ) were dominant on the reference surfaces.

\section{Bacterial community profiles on sponge surfaces}

Terminal restriction fragment length polymorphism revealed that the bacterial community profiles were different on the sponge surfaces and on the inanimate (reference) surfaces. The lowest number of bacterial

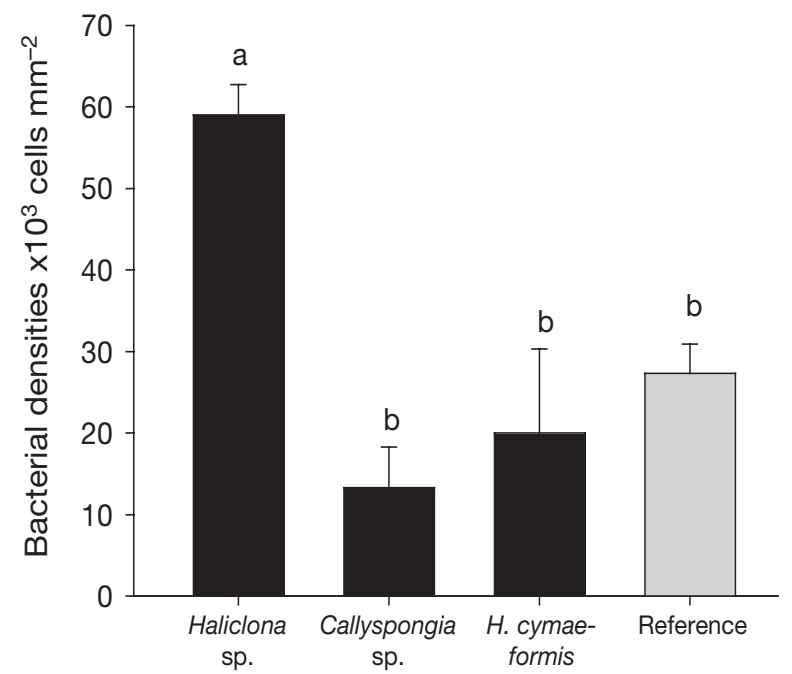

Fig. 1. Bacterial densities (cells $\mathrm{mm}^{-2}$ ) on the surfaces of the sponges Haliclona sp., Callyspongia sp. and Haliclona cymaeformis and a reference site (stones and mussel shells from the close vicinity $>0.5 \mathrm{~m}$ ). Bars indicate mean $\pm \mathrm{SE}$ of 5 replicates. Data that are significantly different according to a Tukey test (ANOVA: $p<0.05$ ) are indicated by different letters above the bars 
ribotypes (TRFs $=28$ ) was recorded from the reference surfaces, while the bacterial communities that developed on the surfaces of the sponges Haliclona sp. and $H$. cymaeformis had double the number of bacterial ribotypes. The highest number of ribotypes $\left(\mathrm{TRF}_{\mathrm{s}}=73\right.$ ) was found in the bacterial communities from the surfaces of Callyspongia sp. Bacterial communities that developed on the surfaces of the sponges had specific TRFs that were not found on reference surfaces (e.g. 43, 122 and $247 \mathrm{bp}$ ). At the same time, each sponge had specific TRFs that could not be found on the surfaces of the other sponges: e.g. $H$. cymaeformis had a specific TRF at $138 \mathrm{bp}$; Callyspongia sp., at $314 \mathrm{bp}$; and Haliclona sp., at 72 bp. Haliclona sp. and H. cymaeformis shared similar TRFs at 120 and $313 \mathrm{bp}$. The presence of common TRFs at 245, 312, 367, 369 and $420 \mathrm{bp}$ on all sponge and reference surfaces might indicate that some bacterial species were not affected by sponge metabolites.

According to the Bray-Curtis similarity matrices, based on the presence (indicated by 1) or absence (indicated by 0 ) of a given TRF in a pattern, the bacterial communities were divided into several groups (Fig. 2). The bacterial communities that developed on the reference surfaces had a low similarity $(<40 \%)$ compared with the bacterial communities that developed on the sponge surfaces, which formed separate clusters. Bacterial communities from the surface of Haliclona sp. and H. cymaeformis shared some similarities and could be combined into 1 sub-cluster in the dendrogram, while communities from the surface of Callyspongia sp. were different from communities on the surfaces of the other sponges.

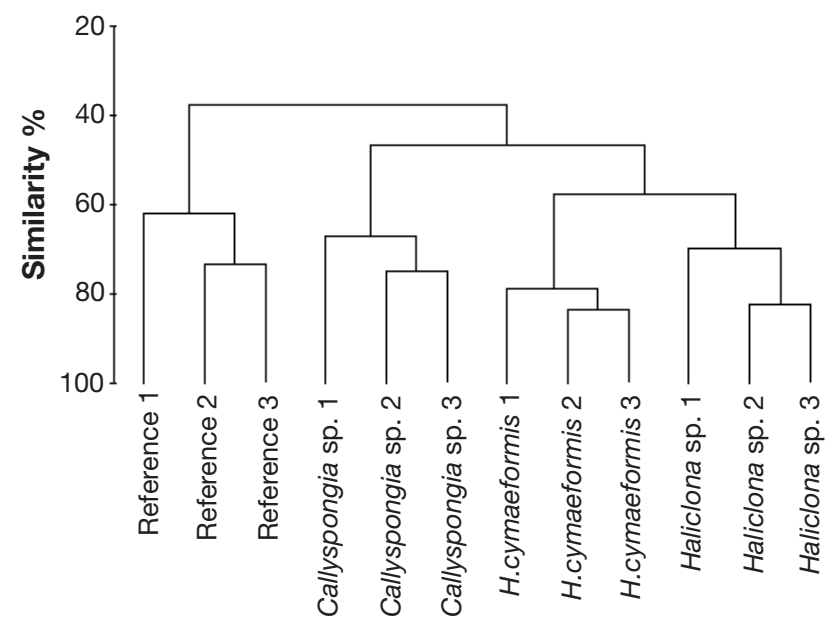

Fig. 2. Cluster analysis indicating similarities between bacterial communities found on the surface of the sponges Haliclona sp., Callyspongia sp. and H. cymaeformis and a reference site (stones from the close vicinity). Different replicates $(\mathrm{n}=3$ ) identified as corresponding numbers

\section{Effect of sponge metabolites on bacterial communities developed on gels}

After $7 \mathrm{~d}$ of the experiments, rod-shaped and coccoid bacteria dominated the bacterial communities on the gels. Epifluorescence microscopical counting revealed that the densities of bacteria on the gel surfaces were significantly different among the treatments (Fig. 3A: ANOVA, $F=14.7, \mathrm{p}<0.05)$. The highest density of bacteria was found on the control dishes and on dishes with $\mathrm{MeOH}$ and DCM extracts of the sponge Haliclona cymaeformis. The lowest densities of bacteria were discernible on dishes with $\mathrm{MeOH}$ extracts of the sponge Haliclona sp., whereas dishes with $\mathrm{MeOH}$ and DCM extracts of Callyspongia sp. had moderate densities of bacteria (Fig. 3A). The MeOH and DCM extracts

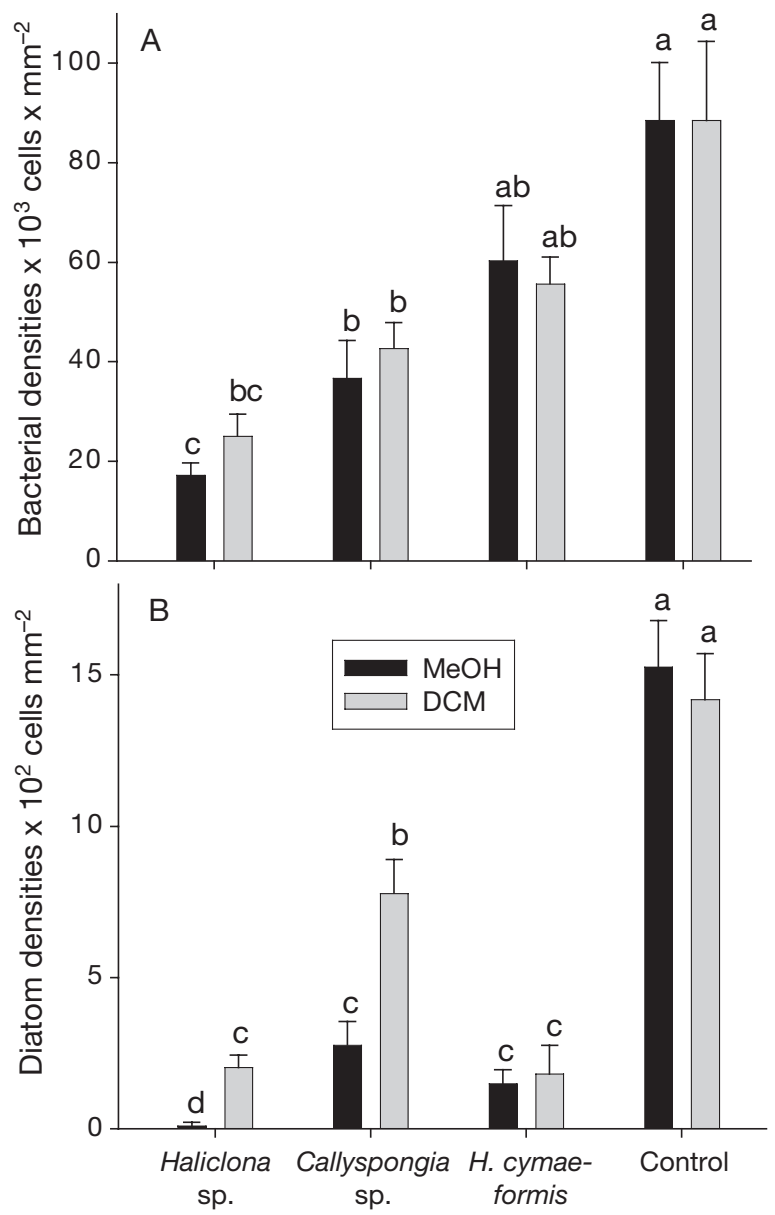

Fig. 3. Densities of (A) bacteria and (B) diatoms that developed on the surface of Phytagel gels after $7 \mathrm{~d}$ of exposure at the university pier at a depth of $1 \mathrm{~m}$ below the low water mark. The gels were enriched with immobilized methanol $(\mathrm{MeOH})$ and dichloromethane (DCM) extracts from the sponges Haliclona sp., H. cymaeformis and Callyspongia sp. In the control, a $4 \%(\mathrm{v} / \mathrm{v})$ solution of DMSO was used. Bars indicate mean \pm SE of 5 replicates. Data that are significantly different according to a Tukey test (ANOVA: $p<0.05$ ) are indicated by different letters above the bars 


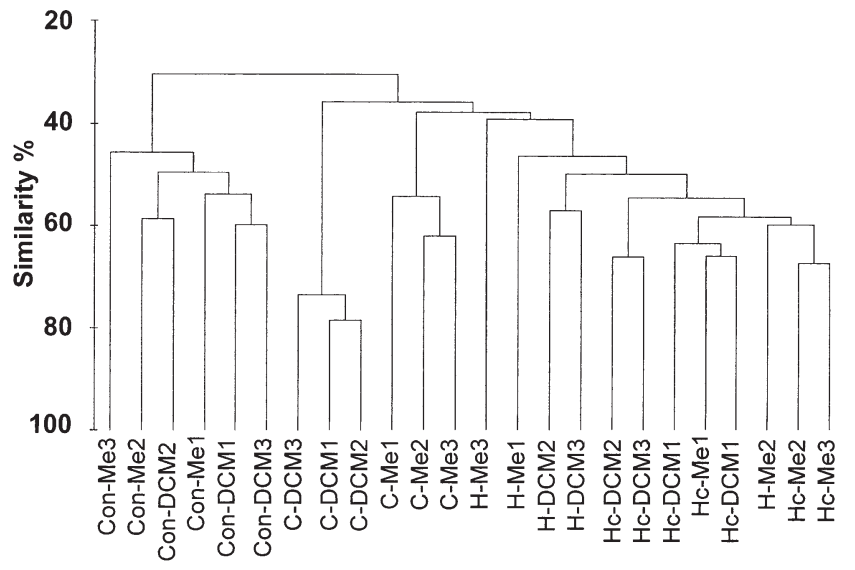

Fig. 4. Cluster analysis of the similarity between bacterial communities that developed on the surfaces of Phytagel gels with immobilized sponge extracts of Haliclona sp. $(\mathrm{H})$, H. cymaeformis (Hc) and Callyspongia sp. (C) derived from methanol $(\mathrm{Me})$ and dichloromethane (DCM) extraction after $7 \mathrm{~d}$ of exposure at the university pier at a depth of $1 \mathrm{~m}$ below the low water mark. Different replicates $(n=3)$ identified by corresponding numbers. In the control (Con), a $4 \%$ (v/v) solution of DMSO was used

of the sponges equally affected bacterial attachment to the dishes.

The maximal number of bacterial ribotypes (TRFs $=$ 166) was found on the control gels, whereas the minimal number (TRFs $=35$ ) was observed on gels with $\mathrm{MeOH}$ extracts of Callyspongia sp. Other gels had a moderate number of TRFs. Absence as well as presence of certain TRFs characterized the bacterial communities developed on dishes with or without sponge extracts. TRFs with lengths of 129, 235, 236 and $240 \mathrm{bp}$ were found only on the control gels. Some bacteria were identified that were not affected by sponge metabolites; their ribotypes (particularly 120, 312 and 584 bp) were present on both the control and on the experimental gels.

According to the Bray-Curtis similarity matrices, the bacterial communities could be divided into several groups (Fig. 4). The bacterial communities developed on the control gels with DCM and $\mathrm{MeOH}$ extracts had a low similarity (about $30 \%$ ) compared with the bacterial communities formed on gels with $\mathrm{MeOH}$ and DCM extracts of the sponges. We found similar bacterial communities on gels with extracts of Haliclona cymaeformis and Haliclona sp. Bacterial communities on the gels with $\mathrm{MeOH}$ and DCM extracts of Callyspongia sp. were different from each other and from the bacterial communities developed on the gels with extracts of H. cymaeformis and Haliclona sp.

\section{Effect of sponge metabolites on diatom communities}

After $7 \mathrm{~d}, 12$ species of diatoms were found on the gels, including Nitzschia longissima, N. constricta, Nitzschia sp. 1, Bacillaria sp., Licmophora sp., Navicula sp. 1, Navicula sp. 2, Navicula sp. 3, Pleurostigma sp., Diploneis sp., Mastogloia pumila and Achnantes sp. We observed the highest densities of diatoms on the control gels. The densities of diatoms on the gels with sponge extracts were significantly lower than those on the control gels (Fig. 3B: ANOVA, $F=9.3$; HSD, p < 0.05). On the surface of gels with $\mathrm{MeOH}$ extracts of Haliclona sp., we observed only 1 species, the diatom $N$. longissima, at very low densities. The densities of diatoms on the gels with $\mathrm{MeOH}$ extracts of Callyspongia sp. and $H$. cymaeformis were moderate. The $\mathrm{MeOH}$ and DCM extracts of the sponges affected the density of the diatoms in a similar way, with the exception of extracts of Callyspongia sp.

The diatom communities that developed on the surfaces of the control gels with DCM and MeOH extracts were similar and were grouped in separate clusters according to the Bray-Curtis similarity matrix (Fig. 5). The diatom communities that formed on the gels with $\mathrm{MeOH}$ and DCM extracts of the sponges were different from each other and formed separate groups. The diatom communities from gels with the $\mathrm{MeOH}$ extract of Haliclona sp. had a low similarity (20\%) with the other diatom communities, forming an independent cluster, while the DCM extracts of this sponge were similar to the DCM extracts of $H$. cymaeformis. Com-

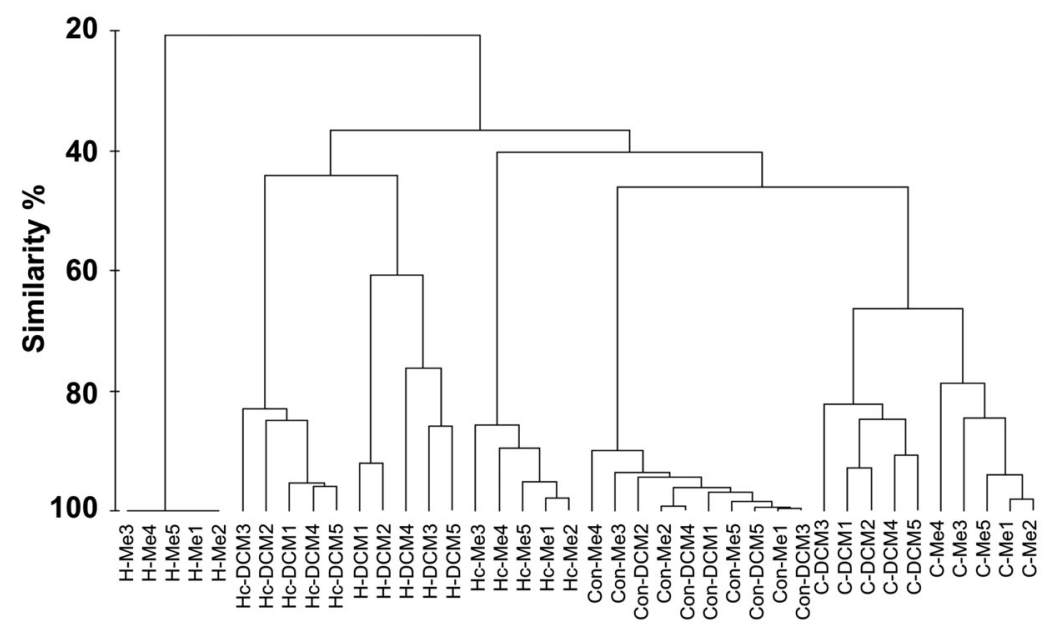

Fig. 5. Cluster analysis of the similarity between diatom communities that developed on the surfaces of Phytagel gels with immobilized sponge extracts of Haliclona sp. (H), H. cymaeformis (Hc) and Callyspongia sp. (C) derived from methanol (Me) and dichloromethane (DCM) extraction after $7 \mathrm{~d}$ of exposure at the university pier at a depth of $1 \mathrm{~m}$ below the low water mark. Different replicates $(n=5)$ are identified by corresponding numbers. In the control (Con), a $4 \%(\mathrm{v} / \mathrm{v})$ solution of DMSO was used 
munities developed in the presence of DCM and $\mathrm{MeOH}$ extracts of Callyspongia sp. formed distinctly related clusters in the dendrogram.

The ANOSIM test provided evidence that the diatom communities on the gels were significantly different according to sponge species (treatment effect: global $\mathrm{R}$ $=0.72, \mathrm{p}=0.001$ ) and the method of extraction (extract effect: global $R=0.35, p=0.04$ ) (Table 1). The SIMPER analysis revealed that 6 diatom species accounted for $>84 \%$ of the total Bray-Curtis dissimilarity among communities from different treatments. The diatom species Nitzschia longissima and Navicula sp. 1 accounted for almost $50 \%$ of the total between-group dissimilarity.

The highest richness and diversity in the diatom communities were found on the control dishes and dishes with DCM extracts of Haliclona sp. and Halichondria sp. (Fig. 6A,B: ANOVA, $F=60.95$; HSD, p < 0.01 and ANOVA, $F=72.02$; HSD, p $<0.01$, respectively). The lowest diversity and richness were found on dishes with $\mathrm{MeOH}$ extracts of Haliclona sp. The lowest evenness was observed in the diatom communities formed in the presence of $\mathrm{MeOH}$ extracts of Haliclona sp., while the evenness of other communities formed in the presence of sponge extracts was similar.

\section{Effect of sponge metabolites on macrofouling communities}

After 3 wk of experiments, we found 1 brown alga (Phaeophyta: Ectocarpales, unidentified brown alga) and 5 invertebrate species (the hydrozoan Obelia sp. [Cnidaria: Hydrozoa]; 2 polychaete species Hydroides elegans and Spirorbis sp. [Annelida: Polychaeta]; the barnacle species Balanus amphitrite [Crustacea: Cirripedia]; and the bryozoan species Bugula neritina [Bry-

Table 1. Results of ANOSIM (global R, p) and SIMPER analysis on the diatom species composition on dishes with Phytagel containing methanol or dichloromethane extracts (extract effect) of sponges and control dishes (treatment effect). The percentage contribution of each factor is averaged over all significant comparisons

\begin{tabular}{|lcc|}
\hline Species & $\begin{array}{c}\text { Treatment effect (\%) } \\
\text { Global } \mathrm{R}=0.72, \\
\mathrm{p}=0.001\end{array}$ & $\begin{array}{c}\text { Extract effect (\%) } \\
\text { Global } \mathrm{R}=0.35, \\
\mathrm{p}=0.04\end{array}$ \\
\hline Nitzschia longissima & 36.7 & 38.0 \\
Navicula sp. 1 & 13.8 & 16.4 \\
Navicula sp. 3 & 11.2 & 12.2 \\
Bacillaria sp. & 9.1 & 14.6 \\
Diploneis sp. & 7.8 & 5.6 \\
Achnanthes sp. & 5.6 & 3.6 \\
Other species & 15.8 & 9.6 \\
\hline
\end{tabular}

ozoa: Cheilostomata]) on the experimental plates. The dominant species on the dishes were the tubeworm $H$. elegans and the barnacle B. amphitrite (Fig. 7). Overall, the settlement of macrofoulers was low, which was not surprising in the cold season in Hong Kong

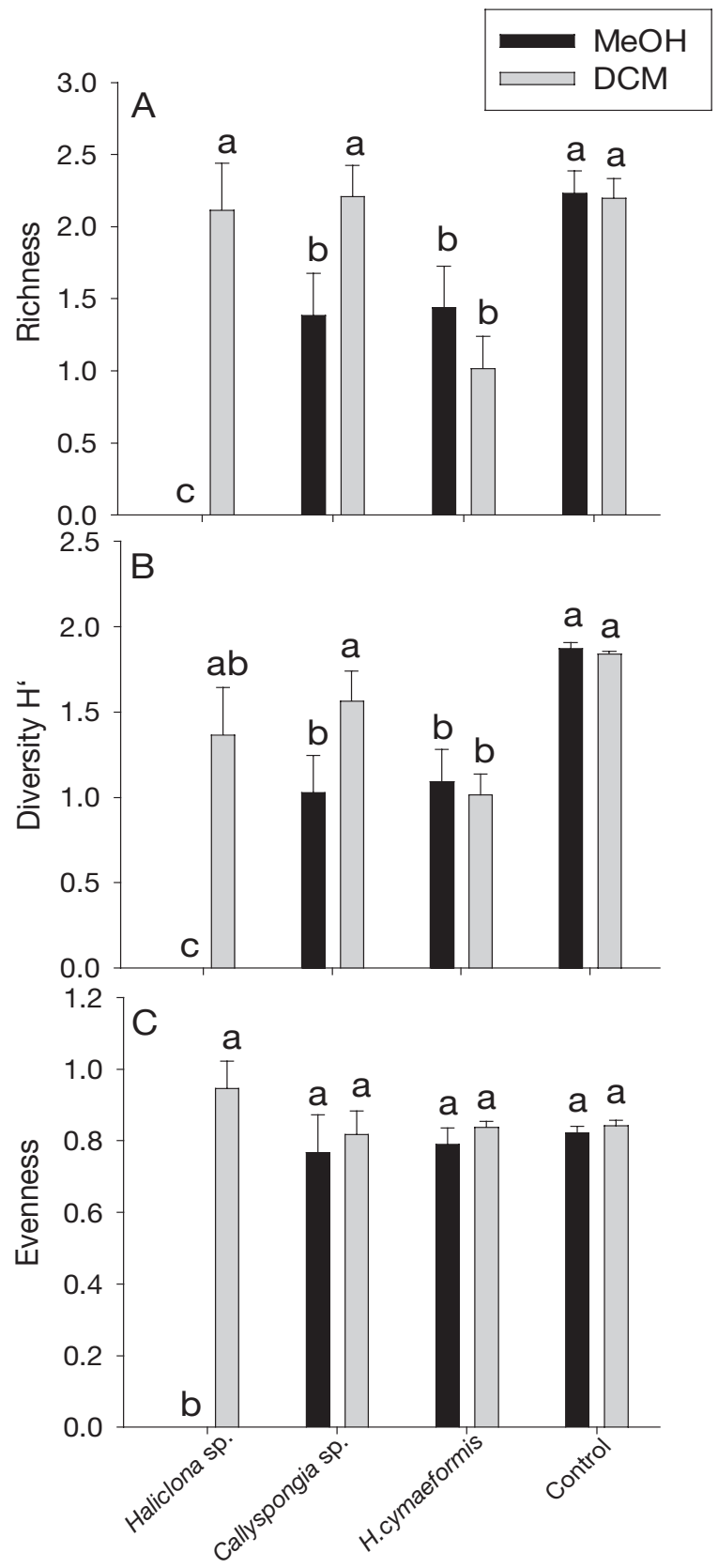

Fig. 6. Effect of methanol $(\mathrm{MeOH})$ and dichloromethane (DCM) extracts of the sponges Haliclona sp., H. cymaeformis and Callyspongia sp. on (A) richness, (B) diversity and (C) species evenness of diatom communities after $7 \mathrm{~d}$ of exposure at the university pier at a depth of $1 \mathrm{~m}$ below the low water mark. Data are expressed as means \pm SE of 5 replicates. Data that are significantly different according to a Tukey test (ANOVA: $p<0.05$ ) are indicated by different letters above the bars 


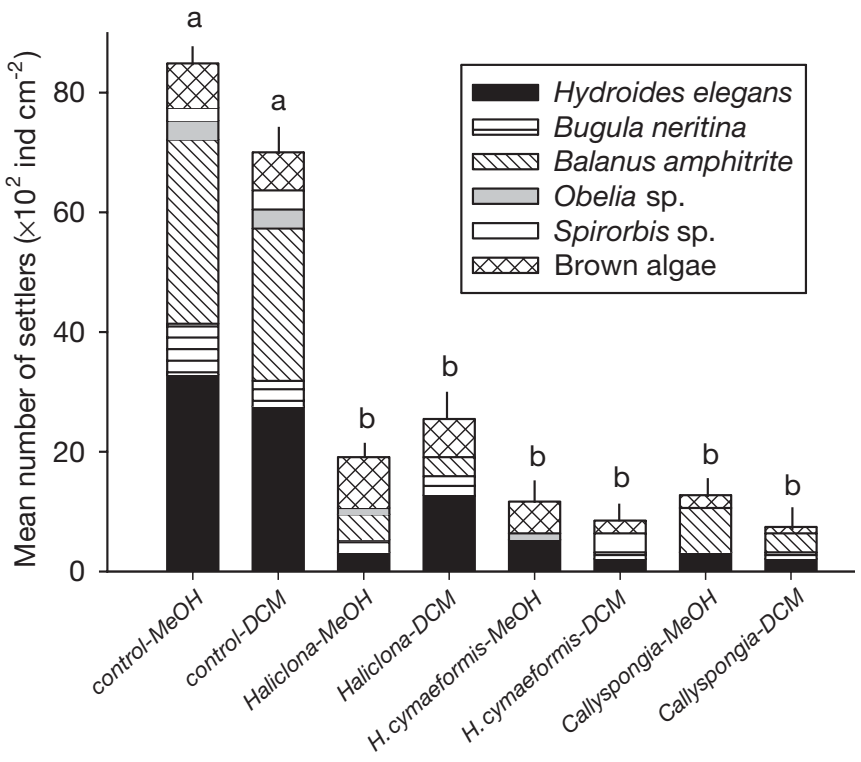

Fig. 7. Densities of macrofoulers (ind $\mathrm{cm}^{-2}$ ) on the surface of gels with methanol $(\mathrm{MeOH})$ and dichloromethane (DCM) extracts of the sponges Haliclona sp., H. cymaeformis and Callyspongia sp. or without them (control) after 3 wk of exposure at the university pier at a depth of $1 \mathrm{~m}$ below the low water mark. Data are expressed as means \pm SE of 5 replicates. Data that are significantly different according to a Tukey test (ANOVA: $p<0.05$ ) are indicated by different letters above the bars

waters (Qiu et al. 2003). Nevertheless, we were able to observe the differences in the settlement of macrofoulers on gels with and without sponge extracts (ANOVA, $F=35.67, \mathrm{p}<0.05$ ). The highest densities of settlers (HSD, p < 0.05) were found on the control dishes, while the lowest settlement density was observed on dishes with sponge extracts. There was no significant difference in the fouling of the gels with $\mathrm{MeOH}$ and DCM extracts of the different sponges.

\section{DISCUSSION}

The present investigation focused on the relationship between the antifouling activity of Haliclona cymaeformis, Haliclona sp. and Callyspongia sp. extracts and epibiosis on the surfaces of these sponges. Our investigation demonstrated that the bacterial diversity on the surfaces of the sponges was higher than the bacterial diversity on inanimate surfaces and that the bacterial composition on the surfaces of the sponges and an inanimate surface was different as well. The density of epibiotic bacteria, according to the SEM pictures, was similar, except on the sponge Haliclona sp., which had double the density of bacteria. We did not detect any diatoms or macrofouling invertebrates on the surfaces of the sponges. These results suggest that sponges can regulate the composition of microbial communities and the assemblages of macroorganisms on their surfaces and that some bacteria may be specifically associated with particular species of sponges. Similar results have been observed by other investigators. Chloroflexi bacteria have been found to be specific to all Aplysina species (Hentschel et al. 2003). The sponges Aplysina aerophoba and Theonella swinhoei from the Mediterranean Sea, Red Sea and Pacific Ocean have a uniform microbial community that is phylogenetically different from that of marine plankton and marine sediments (Hentschel et al. 2002). Moreover, internal (Burja \& Hill 2001, Taylor et al. 2004) and external (Lee \& Qian 2003, 2004) bacterial communities associated with sponges are different from bacterial communities on inanimate objects in close vicinity to the sponges.

Some sponges have been shown to contain large numbers of bacteria (up to $57 \%$ of the sponge volume, cf. Hentschel et al. 2003). This fact may explain the high density of epibiotic bacteria (about $58 \times 10^{3}$ cells $\mathrm{mm}^{-2}$ ) that we found on the surface of Haliclona sp. compared with the bacteria that we observed on the inanimate surfaces and on the surfaces of the other sponge species. No previous work has been done on the density of epibiotic bacteria and other microorganisms on the surfaces of other sponge species, with 3 exceptions. Kelman et al. (2001) reported that no bacteria were found on the surface of Amphimedon viridis. Thakur \& Anil (2000) concluded that the number of colony-forming bacteria on the surface of the sponge Ircinia ramosa ranged from 7 to $9 \times 10^{6}$ colonyforming units $\mathrm{cm}^{-2}$. Since most of bacteria do not readily form colonies on standard agar media (Hentschel et al. 2003), Thakur \& Anil's (2000) experimental work may provide only a rough estimate of actual bacterial abundances on the surfaces of sponges. Finally, Amsler et al. (2000) found a low density of diatoms was on the surfaces of the Arctic sponges Dendrilla membranosa, Leucetta leptorhapsis and Homaxinella balfourensis in January. Although our investigation provides initial evidence on the densities of epibiotic microorganisms on the surfaces of some sponges, further investigations are necessary in order to compare densities of epibionts on different species of sponges and nearby substrata.

The density of the bacteria on the surfaces of the gels with the extracts of the sponges Haliclona sp. and Callyspongia sp. was lower than that on the surfaces of the control gels and on gels with the extracts of $H$. $c y$ maeformis. The bacterial communities that developed on the control and experimental gels were different from each other and were characterized by the absence of certain terminal restriction fragments and the presence of others. Overall, the number of ribotypes on the surface of the experimental gels was 
lower than that on the surface of the control gel. Similar results were obtained in our previous experiments with crude extracts of sponges from Hong Kong and Hainan (Harder et al. 2004, Dobretsov et al. 2005). These differences may be caused by the antibacterial activity of the sponge or by sponge-symbiont-derived metabolites, which decrease the density and the diversity of the bacteria.

In our experiments, bacterial community profiles were compared by using a culture-independent approach, tRFLP. This fingerprinting method is a relatively fast and easy way to provide a semi-quantitative 'snapshot' of community diversity (Fuhrman et al. 2002). It permits quick comparisons of different communities, providing a minimum estimate of the number of different taxa in the sample and some idea about the evenness of their distribution. Nonetheless, tRFLP has certain inherent limitations, including: (1) possible PCR bias, preventing the quantification of the relative abundance in the community (Suzuki \& Giovanni 1996), and (2) the inability to identify different bacterial species, because different bacteria, regardless of taxon, may produce identical TRFs with a given restriction enzyme (Liu et al. 1997). Therefore, false negative results may be obtained in the unlikely event that a sponge extract is utilized by certain bacterial colonizers whose TRFs are the same as those produced by the susceptible bacteria.

The present study revealed that sponge extracts reduced the density of benthic diatoms on gel surfaces. SIMPER analysis showed that the diatoms Nitzschia longissima and Navicula sp. 1 accounted for almost $50 \%$ of the total dissimilarity between communities developed on the control and treatment gels. Similar to the bacteria, our results on diatoms indicate that sponge metabolites affect the recruitment of diatoms, not only in terms of abundance, but also qualitatively in terms of community structure.

After $3 \mathrm{wk}$, we observed the presence of a macrofouling community, which contained 1 algal and 5 invertebrate species. The tubeworm Hydroides elegans and the barnacle Balanus amphitrite were dominant in the community. Similar results were observed in our earlier studies (Qiu et al. 2003). The densities of the macrofoulers were reduced in the presence of sponge extracts. We did not find any differences in macrofouler density between extracts of different sponges, which may have been caused by the low settlement rate during the period of experiments.

How do sponge extracts suppress both micro- and macrofouling? First, sponge metabolites might be toxic to the fouling organisms (Beccerro et al. 1997, Amsler et al. 2000, Lee \& Qian 2003, Dobretsov et al. 2004). Compounds exuded by the sponge Aplysina fistularis, occurring in intertidal areas, were toxic to gastropod veliger larvae of nudibranchs and caused abnormal behavior in all invertebrate adults, as reported by Thompson et al. (1985). The sponge Mycale adhaerens inhibited the larval settlement of the tubeworm Hydroides elegans by excreting toxic waterborne compounds (Lee \& Qian 2003). In our previous experiments, conditioned seawater from the sponge Callyspongia pulvinata was toxic to the benthic diatom Nitzschia paleacea and to $H$. elegans larvae (Dobretsov et al. 2004). Second, sponge compounds might repel propagules of fouling organisms. Although repellent properties of sponge extracts have not yet been described, repellent activities of algal compounds (Sieburth \& Conover 1965, Dobretsov 1999) and bacterial compounds (Chet \& Mitchell 1976, Boyd et al. 1999) have been identified. A third possibility is that the chemical compounds of sponges might affect micro- and macrofouling adhesion. Crude extracts of the Caribbean sponges Ailochroia crassa, Chondrilla nuculata, Ectyoplasia ferox and Iotrochota birotulata inhibited the attachment of the bacterium Vibrio harveyi (Kelly et al. 2003). Finally, sponge metabolites might inhibit growth of micro- and macrofoulers. Inhibition of the growth of diatoms by sponge extracts was described earlier in our laboratory and field experiments (Dobretsov et al. 2004, 2005). However, the actual mechanisms of the suppression of fouling by sponge compounds require further investigation.

The present investigation revealed that, in most cases, there was not much difference in the antifouling activity of the $\mathrm{MeOH}$ and DCM extracts of the sponges. This may be so because most non-polar and medium-polar compounds and organic salts dissolved successfully in both solvents. In the field experiments, only the $\mathrm{MeOH}$ extracts of Haliclona sp. and Callyspongia sp. changed the composition of diatom communities, but the DCM extracts did not initiate any changes. These observations may be explained by the presence of some water-soluble metabolites in the $\mathrm{MeOH}$ extracts of the sponges, which may have antidiatom activity (Dobretsov et al. 2004).

In this study, the results of the field experiments with sponge extracts in most cases corroborated the laboratory observations of epibiosis on the sponge surfaces; in some cases, they did not. For example, we did not observe diatoms on the surfaces of the sponges, but found low diatom fouling on the gels with sponge extracts in the field experiments. We observed high bacterial density and high diversity of bacteria on the surfaces of the sponge Haliclona sp., but extracts of this sponge inhibited formation of bacterial biofilms in the field experiments. We suggested several possible reasons for this surprising result. First, the concentrations of the compounds used in our experiments were different from those to which that bacteria was 
exposed in natural conditions. We used the tissue-level concentration of sponge metabolites, which assumes that there is an equal distribution of sponge compounds (Jensen et al. 1996). However, the distribution of the antifouling compounds in sponges may be different. Moreover, the metabolites released by extraction with solvents may not be released at any appreciable concentration on the sponge surface, but stored inside cells that have no effect on surface biota in the natural environment. Secondly, antifouling protection by the sponges may be a result of various antifouling mechanisms, e.g. phagocytosis, slime production, production of chemical compounds, and/or mechanical defenses by skeletal spicules. Thirdly, the high pumping activity of sponges may cause the passive accumulation of bacteria on the surface of sponges and cause the high density and diversity of bacteria on the surfaces of sponges compared with the surfaces of gels with sponge extracts.

The present investigation demonstrated that sponge metabolites may affect the formation of micro- and macrofouling communities in situ. The presence of high numbers of bacteria on the surfaces of some sponge species was also observed. At the same time, our investigation provided only preliminary information about the antifouling effect of sponge compounds on fouling communities. Further investigations to elucidate the chemical composition of sponge-derived compounds, their mode of action and their effectiveness at natural concentration levels are warranted. Also, other antifouling mechanisms, such as sponge surface topography, wettability, production of slime and the presence of phagocytic surface cells, should be considered.

Acknowledgements. This investigation was supported by Hong Kong RGC grants (HKUST6119/01M, HKUST6100/ 02M, HKUST6240/04M) to P.-Y.Q. The authors thank Y. V. Plakhotnikova and Y. K. Tam (Hong Kong) for assistance in community fingerprint analysis. We thank Prof. Rob von Soest (Amsterdam) for his identification of the sponges collected from Hong Kong waters and Dr. V. Unkefer (Hong Kong) for proofreading the manuscript. The authors thank Prof. U. Hentschel (Germany) for useful comments.

\section{LITERATURE CITED}

Amann RI, Krumholz L, Stahl DA (1990) Fluorescent-oligonucleotide probing of whole cells for determinative, phylogenetic, and environmental studies in microbiology. J Bacteriol 1972:762-770

Amsler CH, Moeller CB, McClintock JB, Iken KB, Baker BJ (2000) Chemical defenses against diatom fouling in Antarctic marine sponges. Biofouling 16:29-45

Austin B (2001) Novel pharmaceutical compounds from marine bacteria. In: Fingerman M, Nagabhushanam R (eds) Recent advances in marine biotechnology, Vol 6. Bioorganic compounds: chemistry and biomedical applica- tions. Science Publ, Gainesville, FL, p 1-19

Beccerro MA, Lopez NI, Turon X, Uriz MJ (1994) Antimicrobial activity and surface bacterial film in marine sponges. J Exp Mar Biol Ecol 179:195-205

Beccerro MA, Uriz MJ, Twan X (1997) Chemically-mediated interactions in benthic organisms - the chemical ecology of Crambe crambe (Porifera: Becilosclerida). Hydrobiologia 355:77-89

Blunt JW, Copp BR, Munro MHG, Northcote PT, Prinsep MR (2003) Marine natural products. Nat Prod Rep 20:1-131

Boyd KG, Adams DR, Burgess JD (1999) Antibaterial and repellent activities of marine bacteria associated with algal surfaces. Biofouling 14:227-236

Burja AM, Hill RT (2001) Microbial symbionts of the Australian Great Barrier Reef sponge, Candidaspongia flabellata. Hydrobiologia 461:41-47

Characklis WG, Cooksy KE (1983) Biofilms and microbial fouling. In: Laskin AI (ed) Applied microbiology. Academic Press, New York, p 93-138

Chet I, Mitchell R (1976) Control of marine fouling by chemical repellents. Proceedings of the 3rd International Biodetermination Symposium. Applied Science Publishers, London, p 515-521

Clarke KR (1993) Non-parametric multivariate analyses of changes in community structure. Aust J Ecol 18:117-143

Clarke KR, Gorley RN (2001) Primer v5: user manual/tutorial. Primer-E, Plymouth

Clarke KR, Warwick RM (1994) Change in marine communities: an approach to statistical analysis and interpretation. Natural Environment Research Council UK, Swindon, p 1-144

Dobretsov SV (1999) Effects of macroalgae and biofilm on settlement of blue mussel (Mytilus edulis L.) larvae. Biofouling 14:153-165

Dobretsov S, Qian PY (2002) Effect of bacteria associated with the green alga Ulva reticulata on marine micro- and macrofouling. Biofouling 18:217-228

Dobretsov S, Dahms HU, Qian PY (2004) Antilarval and antimicrobial activity of waterborne metabolites of the sponge Callyspongia pulvinata: evidence of allelopathy. Mar Ecol Prog Ser 271:133-146

Dobretsov S, Dahms HU, Qian PY (2005) Antibacterial and anti-diatom activity of Hong Kong sponges. Aquat Microb Ecol 38:191-201

Faulkner DJ (2000) Marine natural products. Nat Prod Rep 17: 7-55

Faulkner DJ, Harper MK, Haygood MG, Salomon CE, Schmidt EW (2000) Symbiotic bacteria in sponges: sources of bioactive substances. In: Fusetani N (ed) Drugs from the sea. Karger, Basel, p 107-119

Friedrich AB, Fischer I, Proksch P, Hacker J, Hentschel U (2001) Temporal variation of the microbial community associated with the Mediterranean sponge Aplysina aerophoba. FEMS Microb Ecol 38:105-113

Fuhrman JA, Griffith JF, Schwalbach MS (2002) Prokaryotic and viral diversity patterns in marine plankton. Ecol Res 17:183-194

Harder T, Lau CKS, Dobretsov S, Fang Tsz K, Qian PY (2003) A distinctive epibiotic bacterial community on the soft coral Dendronephthya sp. and antibacterial activity of coral tissue extracts suggest a chemical mechanism against bacterial epibiosis. FEMS Microbiol Ecol 43:337-347

Harder T, Lau SCK, Tam WY, Qian PY (2004) An ecologically realistic method to investigate chemically-mediated defense against microbial epibiosis in marine invertebrates by using TRFLP analysis and natural bacterial populations. FEMS Microbiol Ecol 47:93-99 
Henrikson AA, Pawlik JR (1995) A new antifouling method: results from field experiments using extracts of four marine organisms. J Exp Mar Biol Ecol 194:157-165

Henrikson AA, Pawlik JR (1998) Seasonal variation in biofouling of gels containing extracts of marine organisms. Biofouling 12:245-255

Hentschel U, Schmid M, Wagner M, Fieseler L, Gernert C, Hacker J (2001) Isolation and phylogenetic analysis of bacteria with antimicrobial activities from Mediterranean sponges Aplysina aerophoba and Aplysina cavernicola. FEMS Microbiol Ecol 35:305-312

Hentschel U, Hopke J, Horn M, Friedrich A, Wagner M, Hacker J, Moore B (2002) Molecular evidence for a uniform microbial community in sponges from different oceans. Appl Environ Microbiol 68:4431-4440

Hentschel U, Fieseler L, Wehrl M, Gernert C, Steinert M, Hacker J, Horn M (2003) Microbial diversity of marine sponges. In: Mueller WEG (ed) Marine molecular biotechnology. Springer-Verlag, Berlin, p 59-88

Jensen PR, Harvell CD, Wirtz K, Fenical W (1996) Antimicrobial activity of extracts of Caribbean gorgonian corals. Mar Biol 125:411-419

Jin DX, Chen ZD, Li JM, Junmin L, Li SC (1985) The marine benthic diatoms in China. China Ocean Press and Springer-Verlag, Beijing and Berlin

Kelly S, Jensen PR, Henkel TP, Fenical W, Pawlik JR (2003) Effects of Caribbean sponge extracts on bacterial attachment. Aquat Microb Ecol 31:175-182

Kelman D, Kashman Y, Rosenberg E, Ilan M, Ifrach I, Loya Y (2001) Antimicrobial activity of the reef sponge Amphimedon viridis from the Red Sea: evidence for selective toxicity. Aquat Microb Ecol 24:9-16

Lee OO, Qian PY (2003) Chemical control of bacterial epibiosis and larval settlement of Hydroides elegans in the red sponge Mycale adhaerens. Biofouling 19:171-180

Lee OO, Qian PY (2004) Potential control of bacterial epibiosis on the surface of the sponge Mycale adhaerens. Aquat Microb Ecol 34:11-21

Lee S, Malone C, Kemp PF (1993) Use of multiple 16S rRNAtargeted fluorescent probes to increase signal strength and measure cellular RNA from natural planktonic bacteria. Mar Ecol Prog Ser 101:193-201

Lee YK, Lee JH, Lee HK (2001) Microbial symbionts in marine sponges. J Microbiol 39:254-264

Liu WT, Marsh TL, Cheng H, Forney LJ (1997) Characterization of microbial diversity by determining terminal restriction fragment length polymorphisms of genes encoding 16S rRNA. Appl Environ Microbiol 63:4516-4522

Mercado JM, Carmona R, Niell FX (1998) Bryozoans increase available $\mathrm{CO}_{2}$ for photosynthesis in Gelidium sesquipedale (Phodophyceae). J Phycol 34:925-927

Piel J (2004) Metabolites from symbiotic bacteria. Nat Prod Rep 21:519-538

Editorial responsibility: Otto Kinne (Editor-in-Chief), Oldendorf/Luhe, Germany
Qian PY, Thiyagarajan V, Lau SCK, Cheung SCK (2003) Relationship between bacterial community profile in biofilm and attachment of the acorn barnacle Balanus amphitrite. Aquat Microb Ecol 33:225-237

Qiu JW, Thiyagarajan V, Leung AWY, Qian PY (2003) Development of a marine subtidal epibiotic community in Hong Kong: implications for deployment of artificial reefs. Biofouling 19:37-46

Sera Y, Adachi K, Nishida F, Shizuri Y (1999) A new sesquiterpene as an antifouling substance from a Palauan marine sponge, Dysidea herbacea. J Nat Prod 62:395-396

Sieburth JMN, Conover JT (1965) Sargassum tannin, an antibiotic which retards fouling. Nature 208:52-53

Shapiro SS, Wilk MB (1965) An analysis of variance test for normality (complete samples). Biometrika 52:591-611

Suzuki MT, Giovanni SJ (1996) Bias caused by template annealing in the amplification of mixtures of 16S rRNA genes by PCR. Appl Environ Microbiol 62:625-630

Taylor MW, Schupp PJ, Dahllof I, Kjelleberg S, Steinberg PD (2004) Host specificity in marine sponge-associated bacteria, and potential implications for marine microbial diversity. Appl Environ Microbiol 6:121-130

Thakur NL, Anil AC (2000) Antibacterial activity of the sponge Ircinia ramosa: importance of its surfaceassociated bacteria. J Chem Ecol 26:57-72

Thompson JE, Walker RP, Faulkner DJ (1985) Screening and bioassays for biologically-active substances from forty marine species from San Diego, California, USA. Mar Biol 88:11-21

Thoms C, Horn M, Wagner M, Hentschel U, Proksch P (2003) Monitoring microbial diversity and natural product profiles of the sponge Aplysina cavernicola following transplantation. Mar Biol 142:685-692

Tsukamoto S, Kato H, Hirota H, Fusetani N (1997) Antifouling terpenes and steroids against barnacle larvae from marine sponges. Biofouling 11:283-291

Wahl M (1989) Marine epibiosis. 1. Fouling and antifouling: some basic aspects. Mar Ecol Prog Ser 58:175-189

Wahl M, Mark O (1999) The predominantly facultative nature of epibiosis: experimental and observational experience. Mar Ecol Prog Ser 187:59-66

Walls JT, Ritz DA, Blackman AJ (1993) Fouling, surface bacteria and antibacterial agents of four bryozoan species found in Tasmania, Australia. J Exp Mar Biol Ecol 169:1-13

Warwick RM, Clarke KR (1995) New 'biodiversity' measures reveal a decrease in taxonomic distinctness with increasing stress. Mar Ecol Prog Ser 129:301-305

Webster NS, Hill RT (2001) The culturable microbial community of the Great Barrier Reef sponge Rhopaloeides odorabile is dominated by an alpha Proteobacterium. Mar Biol 138:843-851

Zar JH (1999) Biostatistical analysis, 4th edn. Prentice Hall International, Upper Saddle River, NJ

Submitted: October 8, 2004; Accepted: May 16, 2005

Proofs received from author(s): July 7, 2005 